Article

\title{
The AK Party's Islamic Realist Political Vision: Theory and Practice
}

\author{
Malik Mufti \\ Department of Political Science, Packard Hall, Tufts University, Medford, MA 02155, USA; \\ E-Mail: malik.mufti@tufts.edu; Tel.: +1-617-627-2016; Fax: +11-617-627-3660
}

Submitted: 28 March 2014 | In Revised Form: 26 August 2014 | Accepted: 5 September 2014 |

Published: 8 October 2014

\begin{abstract}
The currently governing Turkish AK Party's reformist agenda at home and its increasingly assertive policies abroad, like the "soft" and "hard" power elements of its foreign policy, reflect a remarkable coherence and continuity in the political vision of the party leadership. That vision - a contemporary manifestation (sometimes described as "neoOttomanism") of an older tradition of Islamic realism - is explicated through a detailed analysis of the speeches and writings of the main AK Party leaders, as well as of their opponents within the Islamist movement, and correlated with actual policy practice. It is further suggested that the AK Party's preoccupation with its traditional secular-nationalist (Kemalist) adversaries has left it unprepared to confront an even more formidable looming challenge: liberalism.
\end{abstract}

\section{Keywords}

AK Party; Davutoğlu; democratization; Erdoğan; Gül; Islamic realism; neo-Ottomanism; Turkey

Issue

This article is part of a regular issue of Politics and Governance, edited by Professor Andrej J. Zwitter (University of Groningen, The Netherlands) and Professor Amelia Hadfield (Canterbury Christ Church University, UK).

(C) 2014 by the author; licensee Cogitatio (Lisbon, Portugal). This article is licensed under a Creative Commons Attribution 4.0 International License (CC BY).

\section{Introduction}

This article seeks to uncover the ideational underpinnings of AK Party foreign policy, on the grounds that this is a time of extraordinary flux in Near Eastern politics, and that at times of such flux the will and intent of political actors gains particular salience. It is clearly the case-as the growing body of theoretically sophisticated literature on the subject recognizes - that as a democratically elected government, the AK Party leadership has had to craft its foreign policies within the context of an interplay between several sets of structural frameworks. Externally, it has naturally been subject to the opportunities and constraints imposed by the regional and global distribution of power. Internally, it has needed to be responsive to popular opinionincluding the growing assertion of diverse identities among an increasingly politically mobilized population-as well as the demands of emergent interest groups and social classes associated with the transition from a statist import-substituting to a neoliberal export-oriented economy. It has also had to deal with an institutional framework (especially the security and judicial bureaucracies) in which its ideological adversaries have long been entrenched.

A focus on systemic constraints, accordingly, can usefully highlight strategic continuities that transcend the varying political and ideological inclinations of particular governments (Gözen, 2010; Oğuzlu, 2010; Özek \& Oğuzlu, 2013). When the Soviet Union assumed a dramatically more aggressive posture in 1945, for example, the magnitude of the geopolitical threat eclipsed the inward-looking and neutralist inclinations of the governing Republican People's Party (CHP), and prompted a rapid alliance with the Western powers. If Russia were to adopt a similarly aggressive posture today, one would expect the AK Party leadership to react in parallel fashion, aligning its policies much more closely in line with those of the United States and NATO than it might currently prefer. By the same to- 
ken, however, such a focus will be less useful in situations where long-standing continuities break down, where the configuration of threats is not as clear, and where there is therefore no consensus on what constitutes an optimal response-such as the impasse reached on the Iraqi Kurdish issue by 2008 , or the outbreak of the Arab Spring in 2011-so that it does matter which particular leadership, with its distinct values and outlooks, is in office. In both cases, it seems likely that a CHP government, for example, would have adopted significantly different policies. For this reason, while the imbalance between Turkish and Russian geopolitical power obviously goes a long way towards explaining the AK Party government's muted response to challenges such as the 2008 Russian-Georgian war (Kardaş, 2013, pp. 648, 654-655) or the 2014 Russian occupation of Crimea, and its preference for nonconfrontational trade-oriented relations instead (iş̧eri \& Dilek, 2011), in a world in which even the most stable dynamics are occasionally upended there is value in knowing how a particular leadership would act if freed from its usual constraints.

Similarly, analyses that focus on Turkey's neoliberal turn-whether positively (Keyman, 2009, 2010; Kirişci, 2009, 2012; Kutlay, 2011) or critically (Uzgel, 2009; Yalvaç, 2012)-do much to explicate the apparently desecuritized, economistic and integrationist features of Turkish behavior, encapsulated in Ahmet Davutoğlu's concept of a "zero problems" foreign policy, and generated (it is argued) by socioeconomic dynamics that transcend the role of the AK Party. Here as well, however, there is a danger of unduly reified theories getting mugged by rapidly changing realities (Kirişci, 2011, p. 46), as evidenced by the recent proliferation of problems between Turkey and many of its neighbors. Davutoğlu, himself, after all, has warned that those "who narrowly focus on the 'zero problems' principle miss Turkey's greater foreign-policy vision", pointing out that it has less to do with "advancing economic and security interests" than with bringing about "Turkey's reintegration with its neighbors" (Davutoğlu, 2013, March 21).

This article's concern with the AK Party's "greater foreign-policy vision" aligns it with those analyses, finally, that hone in on the ideational dimension in the interplay of Turkish foreign policy determinants (Aras \& Fidan, 2009; Balcı, 2010; Bozdağlığlu, 2008; Mufti, 2009; Yanık, 2011). Here again, the challenge is to avoid assigning normative or cultural structures such determinative power that they obscure consequential variations in outlook that grow especially salient at critical transitional junctures. One study that does rise to this challenge is by Bilgin and Bilgiç, who point out that while the AK Party is not the first Turkish leadership to utilize geopolitical discourse in justifying its foreign policies, it is the first to do so by casting Turkey as the leader of its own distinct Islamic "civilizational basin" (Bilgin \& Bilgiç, 2011, p. 191). Published just as the
2011 Arab upheavals were getting underway, however, their article does not have the opportunity to explore the more hegemonistic implications of AK Party geopolitics. Two years later, Duran's equally nuanced analysis likewise recognizes the distinctiveness of the AK Party's "civilizational discourse", and goes on to note the shift from an emphasis on "Europeanization" in its first half-decade in office, to the growing prominence of "Islamic themes" especially after the outbreak of the Arab Spring. Even in this second phase, however, its foreign policy is still described as aiming to avoid polarization and conflict, and continuing to privilege trade relations instead (Duran, 2013, pp. 93, 95).

The objective of this study, accordingly, is to show that AK Party leaders have long maintained a distinctive hegemonistic vision wherein Turkey takes the lead in constructing a reintegrated regional political community-the precise features of which remain unclear-with a shared normative (Islamic) and historical (Ottoman) identity, organized to provide political representation in line with contemporary criteria of legitimacy and consent, and eschewing idealism in favor of realpolitik in order to aim for a position of "greatness" in the international system. This objective will be pursued first of all through a survey of the relevant speeches and writings of key AK Party figures since the early 1990s. Because their ideological vision, like that of any government, is subject to the usual structural and political constraints outlined above, however, the second element of the methodology employed will be to correlate the degree of the AK Party's relative autonomy domestically with the various phases of its foreign policy. By demonstrating that the more freedom of action the AK Party leaders have enjoyed since coming to power, the more their foreign policy rhetoric and practice have conformed to their early 1990s discourse, this approach will confirm the accuracy of the "Islamic realist" neo-Ottoman vision ascribed to them here, while at the same time still giving proper due to the ongoing constraining effects of structural factors.

Such an approach can thus explain the apparent incongruity between the pre- and post-2008 phases of AK Party governance, and provide a response to the liberal call for a renewed focus on domestic reformillustrated by Nathalie Tocci's proposition that "rather than being blinded by ambitions of grandeur, Turkey must realize that its value added in the neighborhood largely hinges on its ongoing domestic transformation" (Tocci, 2012, p. 212) - by showing that far from contradicting each other, the AK Party's reformist agenda at home and its increasingly assertive policies abroad, like the "soft" and "hard" power elements of its foreign policy, actually go hand in hand. In the process, it will become possible to identify the real theoretical and practical pitfalls confronting its attempt to grapple with the pressures of globalized liberalism-the broader ideational/normative framework in which Western 
democracy is grounded, and from which (as will be detailed in the next section) the AK Party leaders have tried to distinguish their own general outlook.

\section{Origins}

Speaking at a conference in 1992, Abdullah Gül, a member of parliament for the Islamist Refah (Welfare) Party, delivered a succinct articulation of the vision that would eventually lead him and some colleagues to break away and found the AK Party, and propel him to the presidency of the republic. He began by asserting that Turkey was undergoing a "systemic crisis" brought about by the incompatibility between Islam and the existing political regime (Gül, 1993, p. 117). Islam provides the basis of "our moral values" and hence of the shared "identity" of the peoples who had been peacefully "integrated" under its banner for centuries (Gül, 1993, pp. 116-117, 119). For the last seventy years, however, he added, Turkey has been ruled by an authoritarian regime-similar in many ways to its counterparts in Iraq, Syria and Libya-whose values are contrary to the values of, and consequently maintains a posture of "enmity" toward, its own people. Gül focused on the two principles of this regime's "official ideology" impinging most directly on political identity: on Secularism, described as an "enmity" toward religion that naturally "alienates" a populace "kneaded together" by Islamic beliefs and values; and on Nationalism, which alienates people still further by promoting a Turkishness that takes the form of "racism" (ırkçılık) and fails to reflect their actual diversity (Gül, 1993, pp. $118,119-120)$. He did not go into the factors that catalyzed Turkey's "systemic crisis" at this precise point in time, but for whatever reasons the authoritarian secular-nationalist ideology had apparently run its course. The most obvious sign was the fact that a part of the population which had long lived harmoniously as part of this community (millet), had now embarked on a "separatist struggle". The Kurdish uprising signals that the Kemalist regime is no longer capable of providing for the moral and material well-being of its citizens, or "even of preserving their unity" (Gül, 1993, p. 118).

This last point led Gül to introduce a new theme, alongside Islamic unity and political representation: greatness. He lambasted Turkey's dominant elites for clinging to a defunct ideology and a bankrupt regime even at the cost of dividing and "diminishing" the country. Abandoning that ideology and regime could not only preserve existing unity, it could bring into being "a new conception" based on Islamic values that would extend to embrace our kinfolk "from Bosnia...all the way to China". For this reason, Gül concluded, the recent emergence of "neo-Ottoman" arguments was a "very healthy" development (Gül, 1993, pp. 124, 125). He elaborated on this theme eight years later:
There are two conceptions in Turkey. The first is an inward-looking conception that considers Turkey exclusively within its borders...that has severed all links to its history...[t]hat might have been appropriate at a certain juncture...but not to current realpolitik conditions... The second conception argues that there are certain realities. Turkey governed this region for so many centuries. It has great potential...History, geography, current events, all oblige us not to ignore [what is happening with] the Turks in Russia, the Circassians, Bulgarians, even in China. I am among those who subscribe to this second conception. (Gül, 2000)

Gül's advocacy of an expansive outlook as a corollary of Islamic identity and representation-all part of the "neo-Ottoman" idea introduced by Turgut Özal during his tenure as Turkey's prime minister and then president between 1983 and 1993 (Mufti, 2009, especially pp. 49-84)-found an echo in another young reformist within the Welfare Party, Recep Tayyip Erdoğan. In an interview published in 1993, one year after Gül's conference speech, Erdoğan defined democracy as the manifestation of the people's will. While as such it is obviously "a fine thing", it is not an end (amaç) in itself but "merely a means" (araç)-a mechanism for instituting any kind of regime the people want (Erdoğan, 1993, p. 419). This statement has since repeatedly been condemned as an expression of Erdoğan's opportunistic use of democratic means for undemocratic ends. The distinction between political means and ends, however, is hardly novel. Political thinkers extending back to the medieval period and beyond have categorized regimes on the basis of their different ends. Al-Farabi (d. $950 \mathrm{CE}$ ), for example, following Aristotle, identified domination as the characteristic end of tyrannical regimes; wealth as the characteristic end of oligarchic regimes; honor as the characteristic end of timocratic regimes; and freedom as the principle of democratic regimes, reflecting the multiplicity of character types and their various different ends accommodated by democracies.

Erdoğan was and is a politician, not a philosopher, so it is unreasonable to extrapolate a political theory from his public statements. Even in this short interview, for example, he seems to contradict himself on the subject of majoritarianism, suggesting at one point that if the people decide democratically in favor of a "totalitarian regime, we must respect that" (but quickly adding that if they want to overthrow such a regime, they must be able to do that as well), then at another point insisting that whereas democracy allows $51 \%$ of the population to dominate the other $49 \%$, "in our opinion, even $99 \%$ have no right to dominate $1 \%$ " (Erdoğan, 1993, pp. 420, 432). Nevertheless, it is evident that he is here trying to balance an affirmation of representation with a concern about the higher ends to 
be promoted in a democracy. So what might those higher ends be? Some clues may be gleaned from Erdoğan's critique of one particular regime which takes up the bulk of his interview.

Erdoğan described the ideology of this regime as a "rigid unitarist conception" with "Kemalism as its religion". Its stunted and repressive outlook had plunged the Turkish economy into continuous decline, "from sixth place in the world in 1923, to 46th today"; induced moral collapse; stifled intellectual progress; and compromised both internal and external security (Erdoğan, 1993, pp. 421-422). Echoing Gül, Erdoğan explained that national unity could never be secured by a "racist official ideology" which insisted that "Turkey is for the Turks" and failed to recognize the " 27 ethnic groups currently living in the Turkish Republic". The regime that governed on the basis of such an ideology had, as a result, "reached a dead end, had begun to decompose, and was emitting disturbing odors...There is no question of Kemalism rejuvenating itself" (Erdoğan, 1993, p. 425). Pressed by the interviewer on whether he therefore believed that the Kurds had a right to break away and form their own state, Erdoğan argued that Kurdish rights could be secured within a framework of "shared faith" and "something resembling the Ottoman states system" (Erdoğan, 1993, p. 422).

Like Gül before him, then, Erdoğan's alternative to what he described as the defunct authoritarian secularnationalist order of Kemalism was a polity held together by the shared moral values and overarching identity of Islam. In distinguishing his understanding of Islamic politics from more liberal concepts of "transformation" and democratization, moreover, he criticized the latter as impositions of "American imperialism" appealing only to those enamored by the "Westernization process", and expressed his resentment at the paternalism of the "Christian" powers which "insistently promote instability and incapacity in Muslim countries" (Erdoğan, 1993, pp. 427, 428-429, 431). The driving animus of his argument, in other words, the higher end at which it aims, is the status of his proposed Islamic polity relative to the existing powers of the world, and it is this concern with status or greatness that led him, as it led Abdullah Gül, to look back to Islam's imperial glory days in search of an alternative to the narrow, Western-inspired, Kemalist nation-state: "Turkey has the power to sustain an imperial vision. In fact, if Turkey wants to take its place as a prestigious member of the global community in the 2000s (and it should), then it is obliged to adopt an imperial vision. The rationales for this obligation lie in its history, its geography, its ethnic composition" (Erdoğan, 1993, p. 430).

Islamic political thought has always accommodated a wide variety of perspectives, and one of the most prominent dichotomies within it has been between what may be called an "idealist" outlook-focusing on Islamic law as an easily comprehensible and imple- mentable blueprint for human perfectibility, whether on an individual or communal level, here on earthand a more "realist" conception which is much more dubious about the capacity of fallible and contentious human beings to reach consensus on the interpretation of divine law, which therefore accords much greater importance to human reasoning and political skill, and which is consequently much more interested in relatively successful, albeit still necessarily imperfect, actually existing political regimes. This dichotomy remains in evidence today. Whereas virtually all Muslims view the earliest years of Islam as a period of divinelyinspired virtuous governance, for example (though they may disagree on how long that pristine age lasted), few Islamists today-whether conservative or militantly revolutionary-look to the subsequent imperial era, from the rise of the Umayyads to the fall of the Ottomans, for political models. Even the Muslim Brotherhood, which has been moving toward increasingly pragmatic positions on political governance, draws little inspiration from the imperial age that constitutes the vast bulk of Islamic history. Herein lies the distinctive realism of AK Party leaders such as Gül and Erdoğan. Their energies focused more on mundane questions-such as how to aggregate the interests of Turks, Kurds, and others within a unified political structure-than on abstract considerations of human perfectibility in preparation for the afterlife, they are accordingly much more open to the lessons and legacies of human history in all its imperfections.

A similar concern with politics as it is actually practiced informs the thought of Ahmet Davutoğlu, a political scientist who became chief adviser to the prime minister after the AK Party's first electoral victory in November 2002, was then appointed foreign minister in May 2009, and became prime minister himself after Erdoğan's election to the presidency in August 2014. At around the same time of the Gül speech and Erdoğan interview outlined above, Davutoğlu published a book entitled Alternative Paradigms asserting the "irreconcilability" of Islamic and Western political worldviews. In the dominant (and especially liberal) currents of the Western tradition, he argued, the "deification of man" reaches such an extent that it alienates the individual both from the rest of society and from the state, so that interpersonal relations take the form of a struggle for individual, primarily material, self-aggrandizement. The Islamic worldview, by contrast, is characterized by the "subordination of economics to politics", a preference for stability and order as opposed to what Davutoğlu considered the West's Machiavellian inclination toward a more competitive or "dynamic" politics, an "equalitarian-solidarist" view of social relations based on "cooperation" rather than "socio-economic stratification", and a "concentration of power through institutional centralization" as opposed to an "institutional pluralism based on the socio-economic disper- 
sion of material power" (Davutoğlu, 1994a, pp. 12, 39, 153; see also p. 103).

Davutoğlu acknowledged that "the pressure of new world forces and the political experience of European nations" have helped in "impressing on the mind of modern Islam" that a "republican spirit" and government through representative "legislative assemblies" are "the only possible form" that the old Islamic ideal of consensus (ijma") "can take in modern times" (Davutoğlu, 1994a, p. 133). While insisting that Islam's distinctive features rule out any automatic "transfer of...Western procedural means of political legitimation" (Davutoğlu, 1994a, p. 198), therefore, Davutoğlu-like Erdoğan-was clearly trying to articulate what he viewed as an Islamically-grounded concept of representative government that avoids the shortcomings of Western liberalism. This effort came at a critical juncture in a broader evolution of Turkish Islamist ideas about democracy and the role of religion in governance.

The evolution itself began in the 1960s when a wave of Turkish translations of books on Islam from all across the world sparked a revival in Islamic political thought (Çalışlar, 1995, p. 76). This was followed by the founding in January 1970 of Turkey's first explicitly Islamist party, the National Order Party, which already in its founding charter called for a "synthesis" of Islamic moral values and a "democratic" political system (Sarıbay, 1985, p. 101). It quickly became clear, however, that serious ambiguities remained between label and content. Thus a 1975 book by the new party's leader, Necmettin Erbakan, called for further populist reforms such as adoption of a presidential system with the president chosen by the people, abolition of the Senate, public referenda on important political issues, and a jury system in the courts (Erbakan, 1975, pp. 30, 44-45). At the same time, Erbakan contrasted his notion of democracy with liberalism, which he described as inspired by an exploitative capitalism that sacrifices the interests of the community to individual greed. He also underscored his illiberalism by attacking the European Union for seeking to turn Turkey into a "colony" as part of a "Zionist" conspiracy, rooted in the Torah, for global control (Erbakan, 1975, pp. 25, 28, 43, 238, 249, 250-251). For Erbakan, then, the attraction of democracy lay primarily in its utility at mobilizing religious populism against Turkey's Kemalist establishment.

Even so, already at this early stage concerns were raised about such an embrace of democracy, no matter how opportunistic. Selahaddin E. Çakırgil, a writer close to Erbakan's party, warned in 1976: "There is an Islamist movement in Turkey today. This movement...is seeking, and finding, legal avenues for its emergence...but the question of whether it will be the principles of democracy, or the principles of our worldview, which will be used as the method for solving our problems, is now confronting us as a serious internal contradiction...Otherwise, while we're saying 'let's use democra- cy', democracy will transform us in its image" (Sarıbay, 1985, pp. 222-223). Such concerns led to a split during the mid-1980s. Some Islamists repudiated democracy altogether, but the dominant current-responding to contemporary realities, just as Çakırgil had warned-came to see themselves as "Muslim democrats" (Çakır, 1994, pp. 112, 113, 115). As one of the participants in these debates, Bahri Zengin, later remembered, those who balked at defending freedom of opinion-because it would mean defending the rights of communists as well-ended up outnumbered by those accepting that they should "defend this not as a tactic" but as a genuine "component of our values" (Çalışlar, 1995, pp. 80-81).

An instructive example of this evolution can be seen in the writings of the Islamist intellectual Ali Bulaç. Looking for a model in the "Medina Constitution" implemented by the Prophet Muhammad and ratified by the various communities of that multi-religious first capital of Islam, Bulaç in 1992 affirmed the principles of pluralism, legal and cultural autonomy for every religious and ethnic group, and a participatory politics in which the executive authority acts more as "referee" than "ruler". He accordingly argued that the Constitution stood "above" the Qur'an, Torah, and various local customs because the Islamic community (ümmet) of that time was a "political union" in which Muslims, Jews and polytheists coexisted (Bulaç, 1992). At the same time, like Davutoğlu, Bulaç resisted identifying this Islamic model with Western liberalism. In a 1993 book, he described the latter as unwieldy, characterized by an inordinate "competitiveness" that is a product of the West's distinctive history, and ineffective at achieving justice and distribution of rights (Bulaç, 1993, pp. 22, 33, 39, 63-65). Eight year later, however, Bulaç had come around to a much more positive view. While still maintaining "our fundamental objection" to the Western Enlightenment's excessive individualism, he called for a reconciliation between Islam as a religion and democracy as a "political regime", asserting that it was indeed possible to speak of "Islamic democracy" (Bulaç, 2001, pp. 9, 34, 111). This was because the inevitable multiplicity of interpretations ruled out any undisputed application of divine law. The "fundamental question", Bulaç concluded, was:

In whose name do those who govern us govern? In the name of God? No. Because the governors are not God's representatives. In whose name does the president of the republic or the mayor of Istanbul, for example, govern us? In our name. Who gave this authority to the president or the mayor? We gave them the authority to govern us. In that case we can say: in a proper political arrangement, the right to practice sovereignty and to transfer authority belongs to the community (ümmet), to the people. (Bulaç, 2011, pp. 41, 60) 
As will be shown presently, this accommodation of democracy would prove about as far as Bulaç would go in reconciling his ideals with the imperatives of realpolitik.

It was at such a juncture in the evolution of Islamist views on democracy, at any rate, that Ahmet Davutoğlu's 1994 book appeared. In line with the emerging consensus, he was prepared to accept the institutional mechanisms of representation developed by the Western democracies. Again in line with that consensus, however, he saw little tension between the rights of the individual and the requirements of the state: "The aim of the state is the fulfillment of justice on behalf of Allah on earth...The perfection of the individual is connected to the fulfillment of this mission by an ideal state in the writings of several Muslim scholars" (Davutoğlu, 1994a, p. 107). Beyond assigning the state a higher and more central role in human selfrealization than it plays in liberal Western political thought, moreover, Davutoğlu also defined it differently, rejecting the "nation-state" as "a purely Western artifact" in favor of an overarching, multicultural "Islamic polity" capable of serving "as an alternative worldsystem" (Davutoğlu, 1994a, pp. 165, 202). In a second book published in 1994, he elaborated on this distinctive Islamic state system: "This will encourage Muslims to revitalize traditional concepts such as the Ummah universal brotherhood, Dâr al-Islâm as a world order and the Caliphate as the political institutionalization of this world order. It is not necessary to have the traditional forms of these institutions" (Davutoğlu, 1994b, p. 113).

Davutoğlu's greatest impact, however, came with his third book, Strategic Depth, published in 2001. Although he would later shy away from the label "neoOttomanism" because of its expansionist connotations, Davutoğlu made it clear here that his objection to "Özal's neo-Ottomanist line" lay primarily in the "journalistic level" at which it remained due to its "theoretical underdevelopment" (Davutoğlu, 2007, p. 90). Instead, he proposed to expose, rigorously and systematically, the "most fundamental contradiction" in Turkish foreign policy: the "historic break" between Turkey's imperial past as the "political center of its civilizational environment" and its current structure as a "nation-state". The reason for this break was the desire of the postOttoman "political elite" to attach itself to "another civilizational environment", the West (Davutoğlu, 2007, pp. 81-83). Under the guidance of these "identitylacking elites" (kimliksiz seçkinler), Turkish foreign policy had acquired a "defensive", "reactive", "cowardly", and "timid" outlook that completely disengaged from all "the lands over which sovereignty had been lost", and anxiously sought only to preserve the "new lines" of the Republic's borders (Davutoğlu, 2007, pp. 33, 47, 53). Because such a stance ignored-"arhythmically" and "aharmoniously" - the political-cultural resonances between the republican and imperial environments, Davutoğlu concluded (echoing Erdoğan and Gül), it would ultimately fail even to secure the existing status quo (Davutoğlu, 2007, pp. 117, 555).

Instead, Turkey should adopt a strategic posture more in harmony with its historical legacy: one capable of transmuting its liabilities into power assets by "venturing outwards with confidence and assertiveness" rather than closing in on itself; one that could enable its people to "write" rather than merely "read" their own "history" (Davutoğlu, 2007, pp. 11, 555, 560). Such a strategy would necessarily utilize a wide range of mechanisms, and Davutoğlu devoted considerable space in his book to the types of institutions through which Turkey could reengage with its geopolitical environment. This institutional focus, coupled with Davutoğlu's care-here, as well as subsequently in his career-to maintain a cooperative tone, has misled many readers into seeing him as an exponent of the liberal "post-security" school of international relations theory. A closer look at his treatment of the three main arenas of Turkish foreign policy, however, reveals a more complex picture.

Toward the north, Davutoğlu called for a more "dynamic" and "audacious" (atak) stance, informed by one massive underlying reality: "the historic Ottoman/Turkish-Russian/Soviet/Russian rivalry". Such a stance need not be unduly provocative; indeed, it should recognize that there can periodically be periods of cooperation with Russia for common benefit or against a common threat (Davutoğlu, 2007, pp. 56, 240). But its overall thrust should aim at "balancing Russia's influence over Central Asia and the Caucasus", and even at "strengthening by stages the status of the North Caucasus republics inside the Russian Federation". Davutoğlu left no doubts about the fundamentally conflictual nature of this agenda by noting that "the greatest element in breaking Slavic and Russian influence in these regions is the counter-cultural resistance power provided by Islam" (Davutoğlu, 2007, pp. 181, 250).

If its borders with the Russian sphere of influence formed Turkey's primary geopolitical front line, the Middle East constituted its "indispensable hinterland" (Davutoğlu, 2007, p. 129). Turkey would need to build up this hinterland by neutralizing its rivals there, old (Iran) and new (Israel), and by restoring its traditional alliances-above all, with the Kurds and Arabs. In the case of the former, this would require the adoption of "a new cultural approach that encompasses all peoples", so that the Kurdish issue could go from being a liability that rendered Turkey "vulnerable to external pressures" to a power-projection asset in its own right (Davutoğlu, 2007, pp. 442, 448). In the case of the latter, it meant reversing the "alienation" from the Arab world caused by "indexing" Turkey's policies to Israeli interests (Davutoğlu, 2007, pp. 57, 415-416).

As for the European arena, Davutoğlu advocated "actively" supporting formerly Ottoman Muslim communities in the Balkans such as the Albanians and Bos- 
nians; safeguarding Turkey's vital interests in Cyprus and the Aegean islands (where the prospect of war loomed largest because of the "unforgiveable errors" of the Kemalists in failing to formulate a "coherent naval strategy"); and playing the competing ambitions of the Russians, Germans, and Americans off against each other (Davutoğlu, 2007, pp. 122-123, 154, 235, 293$294,315-316,528)$. A similar realpolitik logic characterized Davutoğlu's discussion of the European Union, which is described as an element balancing both American and Russian power, so that the primary purpose of accession would be to maximize Turkey's own room for strategic maneuver (Davutoğlu, 2007, pp. 520, 550).

It becomes apparent, then, that Davutoğlu's utilization of language and concepts characteristic of liberal international relations theory obscures an underlying logic much more in line with realist-indeed, imperial-conceptions. That this is true of his and his colleagues' political worldview more generally, will become clearer when we turn to the AK Party's actual practice after it came to power in 2002.

\section{Consolidation Phase (2002-2008)}

In a book written after the AK Party assumed power, Ali Bulaç noted its apparently fully internalized espousal of democracy and-in line with the evolution of his own thought outlined above-agreed with it to some extent (Bulaç, 2010, pp. 350-351, 442). He worried, however, that by embracing designations such as "conservative" and "reformist" rather than "Islamic", the new party intended to "set Islamism aside" in order to accommodate the "civilian-military bureaucracy, big capital...the United States and the European Union" (Bulaç, 2010, pp. 17-18, 50-51). Just three years after taking office, he complained, its materialistic policies had already created a corrupt environment that allowed certain coteries to "loot" public resources. If this was the model of reconciling "Islam and democracy" that the AK Party hoped to "market" to other countries, then it would be exporting "the empty and purposeless life style of a nihilistic culture" and thus "dragging...the Middle East and neighboring regions to suicide alongside Turkey" (Bulaç, 2010, pp. 208, 441-442).

Bulaç found the AK Party's foreign policy equally objectionable-especially its support for the "savage...unjust and illegal" American war on Iraq, its cooperation with the American military campaign "against the Muslim Afghan people", and its unwillingness to suspend "at least a few" of Turkey's bilateral agreements with Israel (Bulaç, 2010, pp. 126, 312, 407). Here as well, the AK Party was in danger of losing its moral grounding. All this, Bulaç argued, grew out of a "realist" outlook evident throughout the history of Islam-a "Real-Islam" (Reel İslam) that effaces the religion's "life-giving values" (Bulaç, 2010, p. 52). An "excessive emphasis on realpolitik paves the way for the surren- der of principle and justice to security, of the ideal to [contingent] conditions". This is what had happened to the erstwhile Islamists of the AK Party, for whom "everything became politicized": "Muslim intellectuals suddenly became state bureaucrats, and they all began to concern themselves with strategies for Turkey's regional leadership...[They] lost their autonomous and civilian character and came to resemble the Ottoman official clergy $($ ulema)...This is the first of the greatest disasters to befall the Islamist movement" (Bulaç, 2010, pp. 24, 450, 448).

The AK Party's early public discourse certainly appeared to confirm such observations. Even before taking office as prime minister, Erdoğan told an audience in Washington that his party was "realistic and reformist" and, while it "represents the common values" of Turkey's "moderate Muslim population", was not itself "based on religion". He stressed that "democracy represents my belief in what type of government there should be" and that: "We favor free market economy. We are against state oriented approaches". As for foreign policy, "a government under AK Party will make the Turkey-U.S. alliance stronger" (Erdoğan, 2002). Action followed words, with AK Party parliamentarians voting on 1 March 2003 to cooperate with the United States in opening a northern front against Iraq-a resolution that nevertheless failed due to opposition parliamentarians backed by Kemalist circles in the military-and on 30 July 2003 to pass a landmark legal package that advanced democratization by curtailing the authority of the military-dominated National Security Council. Another milestone came on 12 August 2005 when Erdoğan capped a series of measures enhancing minority cultural rights by going to Diyarbakır, the main city of Turkey's Kurdish region, where he acknowledged Turkey's "Kurdish problem" and said it could only be solved through more democracy.

As this brief overview indicates, Erdoğan and his colleagues focused their energies at this stage on domestic reforms-deploying their electoral mandate as well as the EU's accession criteria in order to consolidate civilian authority, to jumpstart a moribund economy that in 2000-2001 had experienced the worst financial crisis since World War II, and to lay the groundwork for a resolution to the long-simmering Kurdish uprising. The most sensitive foreign policy issues (above all Iraq) remained largely in the hands of the military, while the diplomats pursued Davutoğlu's "zero-problems" approach, centered on containing regional crises and pushing ahead with the EU accession process, in order to create a stable environment for the domestic political transition and economic recovery. Davutoğlu himself emphasized the "continuity" in Turkey's foreign policy, for example in maintaining its "red lines" against Kurdish separatism in northern Iraq, explaining in 2004 that the overall priority was "to minimize external threats as much as possible so that 
sound reforms can be implemented at home" (Davutoğlu, 2013, pp. 90, 162).

This combination of reform at home and crisis control abroad proved remarkably successful. Real Gross Domestic Product rose by an average of $6.8 \%$ annually between 2002 and 2007, leading the Financial Times to describe the five-year cumulative expansion as the "longest and most stable stretch of uninterrupted growth since at least 1970" and making Turkey the 17th largest economy in the world (Boland, 2007, April 2; Macovei, 2009, p. 10). A series of legal and administrative reforms expanded freedoms for both individuals (for example through the establishment of a Bureau for Review of Allegations of Human Rights Violations in 2004) and for communal groups (for example with the initiation of news broadcasts in Kurdish and other minority languages on state television in 2004). As national elections in 2007 approached, however, Turkey's Kemalist establishment moved to try to reverse the AK Party's fortunes.

Chief of Staff Yaşar Büyükanıt fired a major salvo in mid-February 2007, warning that the "Turkish Republic had not confronted as great risks, dangers and difficulties since 1923" (Hürriyet Newspaper, 2007, February 14). Speaking at the Istanbul War Academies two months later, President Ahmet Necdet Sezer elaborated, saying that "foreign forces" and "systemic powers"-annoyed that Turkey was maintaining its "Atatürkist structure" and resisting full incorporation into the "hegemony of the global system" - sought to destroy Turkey's sovereignty by engineering its transformation from a "secular republic" to a "democratic republic" and finally to a "moderate Islamic republic". Sezer described his duty and that of the Constitutional Court as being to "balance and put the brakes on" the elected government's "dictatorship of the majority" (Radikal Newspaper, 2007, April 14). The following day, a series of coordinated mass demonstrations, with chants of "No to America, no to the EU, down with the government", got underway in Turkey's largest cities. When the AK Party nominated Abdullah Gül later in April for president (to succeed Sezer), the General Staff posted a statement on its website asserting the Turkish Armed Forces' determination to act as the defender of secularism. But the campaign failed, and the AK Party scored a crushing victory in the 22 July 2007 national elections, winning $47 \%$ of the popular vote (compared to $34 \%$ in 2002) and 341 of 550 parliamentary seats. Gül for his part overcame a series of legal challenges and was elected president by the new parliament in August.

Turkey's hardliners suffered a second setback seven months later, this time in foreign policy. Throughout 2007, General Büyükanıt had been arguing for a military incursion into northern Iraq in order to destroy the PKK and its Iraqi Kurdish backers once and for all. Erdoğan, by contrast, voiced reservations: "It is said that there are 500 terrorists in northern Iraq. There are 5000 terrorists in Turkey's mountains. Has the struggle against these 5000 terrorists inside Turkey been completed...that we should move to contending with the 500 persons in northern Iraq?" (Radikal Newspaper, 2007, June 13). Undeterred by Erdoğan's evident desire to have the military assume full responsibility for the proposed operation, and despite repeated warnings by American officials against the idea, a series of artillery and air strikes across the border gave way to a fullscale land invasion on 21 February 2008. On 27 February, U.S. Defense Secretary Robert Gates said: “It's very important that the Turks make this operation as short as possible and then leave...I measure quick in terms of days...not months" (Oppel \& Al-Ansary, 2008). On 29 February, Turkish troops completed their withdrawal.

The incursion weakened the AK Party's opponents in two ways. First, the practical results -240 PKK fighters and 27 Turkish soldiers killed according to Turkish officials; 5 Kurdish fighters and 130 soldiers killed according to the PKK-fell so far short of expectations that it prompted expressions of disappointment and recrimination even from parties normally aligned with the military. Second, the failure of the operation revealed the bankruptcy of the Kemalist approach to the Kurdish question, and opened the way for alternatives. In early March, Admiral William J. Fallon, the head of US Central Command, called on "the Turks" to reach "some kind of accommodation" with "this group" and "not just try to eliminate them militarily" (Reuters, 2008, March 10). Secretary Gates reiterated the need "to try and address some of the civilian concerns among the Kurdish population...I think the real objective is to peel away from the hard-core terrorists those who might be reconciled and brought back into the political fold" (US Embassy in Ankara, 2008).

Together the national elections of July 2007 and the Iraq debacle of February 2008 constituted a turning point that shifted the balance of power decisively between the AK Party and the Kemalist establishment. Already in late January 2008, following unprecedented leaks of documents detailing alleged coup plots by top military officers, a series of arrests and prosecutions got underway which would eventually put some $10 \%$ of all serving generals and about half of all admirals, as well as hundreds of civilian alleged co-conspirators, behind bars. Further leaks and revelations-variously blamed on more democratic elements in the Turkish Armed Forces seeking to purge their hard-liner colleagues, or on sympathizers of Fethullah Gülen's Islamist Hizmet movement within the police and judiciaryleading to further arrests, forced retirements and resignations, appeared to signal the effective defeat of the authoritarian secular-nationalist power structure. With the domestic consolidation phase successfully completed, then, Erdoğan and his colleagues could pursue their own priorities more freely, and in the process to 
answer the questions raised by Ali Bulaç and many others about the true character of their political agenda.

\section{Transition Phase (2008-2011)}

Domestically, the further strengthened AK Party moved quickly toward reconciliation with the Kurds - the obvious and indispensable first step for any meaningful reform agenda. On 11 March 2008, President Gül met with the leader of the Kurdish-based Democratic Society Party (DTP), and later declared that no one, including the military, believed any longer that "this thing can be solved by arms" (Cemal, 2008, March 14). A few days later, a DTP parliamentarian reciprocated with an article defending the AK Party against a final (and abortive) party closure case launched by the State Prosecutor, and calling for an alliance against the "anti-pluralistic, coup d'étatist, fascistic, neo-Unionist forces" (Tuğluk, 2008, March 17). On 29 July 2009, Interior Minister Beşir Atalay unveiled a major initiative that came to be known as the "Kurdish Opening" entailing an array of further human rights and cultural reforms-prompting denunciations by the two main opposition parties, the Republican People's Party (CHP) and the Nationalist Action Party (MHP).

Externally, the most important development of this phase also aimed at Kurds. In the immediate aftermath of the failed military incursion of February 2008, the AK Party government undertook one of the most dramatic turnarounds in the history of Turkish foreign policy. After decades of attempting to suppress Kurdish autonomy in northern Iraq, Turkey initiated a rapprochement that bore the potential of upending the entire regional balance of power. A meeting between Turkey's Special Envoy to Iraq Murat Özçelik and Nechirvan Barzani, prime minister of the Kurdish Regional Government (KRG), on 2 May 2008 led to an announcement that Turkey would open a formal dialogue with the KRG. Several high-level meetings between the two sides ensued, culminating in an unprecedented meeting in Baghdad on 24 March 2009 between President Gül and Prime Minister Barzani, at which Gül declared that once the PKK issue was resolved, "there are no bounds to what is possible: you are our neighbours and kinsmen" (De Bendern, 2009, March 25). The full import of Gül's comments began to emerge in early 2010, with the reopening of the Gaziantep-Mosul rail line, the opening of a Turkish consulate in Erbil, and the announcement by the KRG that it sought to export 100,000 barrels of oil per day through Turkey.

Just as the AK Party's domestic Kurdish opening could easily be explained as part of a broader liberalizing political agenda, its moves in northern Iraq could also be justified in functionalist, liberal terms-for example in Ahmet Davutoğlu's repeated insistence that his government's approach rested more on "economic interdependence" and "cultural influence" than on power or "deterrent superiority and threat" (Davutoğlu, 2013, p. 302). The same could be said for other aspects of Turkey's external relations during this period: the steady growth in the share of external trade in GDP from $43 \%$ in 2000 to $52 \%$ in 2008 to $58 \%$ in 2012 (World Bank, n.d.); a proliferation of free-trade agreements (from just 4 before 2002 to 11 by 2007 and 18 by 2012) (Turkish Ministry of Economy, n.d.); infrastructural integration with neighboring countries exemplified by intensified transportation links (the Gaziantep-Mosul line as well as plans for a GaziantepAleppo fast train service and for reopening longdisused links along the old Hijaz Railway; a dramatic increase in Turkish Airlines flights, especially to the Middle East and the former Soviet Union) and by plans for a regional seven-country electricity grid (International Crisis Group, 2010, pp. 11-12); and: "Since 2009...a systematic policy of visa liberalization...[through] a series of bilateral visa-free agreements with countries in its neighborhood" (Evin et al, 2010, p. 19). Finally, further reinforcing this apparent embrace of regional interdependence and integration, of soft rather than hard power, was Turkey's pacific ("zero-problems") stance during this period toward old rivals such as Russia, as reflected by its subdued response to the 2008 RussianGeorgian war, and by the establishment of a bilateral "High-Level Cooperation Council" in May 2010.

No wonder, then, that many observers believed a decisive shift from realpolitik to liberal integrationism had taken place in Turkish foreign policy. For some, this was cause for concern: one Turkish analyst complained that the AK Party government's adherence to "liberal dogmas" and its "allergy" to "the use of force" had produced an "excessive optimism" that reached "Pollyannaish" levels (Koç, 2010, pp. 3, 6). Foreign interpretations were generally more favorable. The International Crisis Group noted the "win-win attitude which has become a catchphrase of Turkish diplomacy, by contrast with the zero-sum equation that traditionally has dominated the region" (International Crisis Group, 2010, p. 13). Several Western authors in a 2012 edited volume welcomed the "sharp contrast" with earlier Turkish foreign policy (Tolay \& Linden, 2012, p. 2), arguing that whereas in the 1990s it had been "largely framed within a realist understanding", now it sought "to promote peace and regional integration" (Tocci \& Walker, 2012, pp. 35-36), and concluding that as "Turkey has become more democratic and Europeanized", its external policies have grown "far more cooperative and constructive" (Tocci, 2012, p. 206).

At the same time, however, other observers had begun to evince disquiet. An early indication came with the three-week Israeli assault on Gaza in December 2008. Prime Minister Erdoğan, who had heretofore balanced his criticisms of Israel's treatment of the Palestinians with ongoing Turkish-Israeli economic and se- 
curity cooperation, adopted a much sharper tone, denouncing Israel's "inhumane actions" and, on 29 January 2009, engaging in his famous outburst against Israeli President Shimon Peres at the Davos conference. Tensions reached a new peak on 31 May 2010 when Israeli troops attacked a Turkish flotilla seeking to break Israel's blockade of Gaza, killing nine activists. With anti-Israeli sentiment at a peak in Turkey, the AK Party government's downgrading of bilateral relations enhanced its popularity domestically as well as among the Arab masses. It was a different story on the governmental level, however. The same 2010 ICG report referenced above also cited Syrian officials who worried that northern Syria "may slip into a Turkish sphere of influence"; an Egyptian official who complained that Erdoğan "seemed to get drunk on the response to Gaza statements"; a Saudi official who said: "They forget themselves. If this influence is going to spread again, this is very dangerous to me as an Arab"; and another Syrian official who warned: "We hear they have Ottoman ambitions, or that they want to take this region under their umbrella. Who will let this happen? Nobody" (International Crisis Group, 2010, pp. 11, 21).

Foreign Minister Davutoğlu continued to deny any "neo-Ottoman agenda" and to insist that the "key word defining Turkey's relations with the Arab countries is not 'hegemony', but 'mutual cooperation'" (MacLeod, 2012). As an unnamed Arab diplomat in Ankara put it, however: "Turkey talks about everything, solving problems, multilateral economic cooperation, interdependence. The only problem is that they are the main beneficiary. They have the industries, the skilled labourers. We have only oil and gas in our favour" (International Crisis Group, 2010, p. 11). The diplomat's words suggest an alternative, less liberal, interpretation of AK Party foreign policy in which economic and cultural openness reflect economic and cultural dynamism, and political engagement reflects political confidence. As students of politics have long been aware, after all, hard and soft power go hand in hand, andpace Davutoğlu-openness is a natural characteristic of hegemony. Still, the full extent of the AK Party's ambitions would not become clear until after its next major milestone.

\section{Implementation Phase (2011-)}

The AK Party won its third straight national election on 12 June 2011, once again raising its share of the total vote (from $34 \%$ in 2002 , and $47 \%$ in 2007 , to $50 \%$ ). In his victory speech that night, Erdoğan declared the outcome "Sarajevo's victory as much as Istanbul's; Beirut's victory as much as Izmir's; Damascus' victory as much as Ankara's; Ramallah's, the West Bank's, Jerusalem's, Gaza's victory as much as Diyarbakır's...Turkey has now attained a democratic freedom that is an example for its region and the world" (Hürriyet Newspa- per, 2011, June 12). Speaking at a gathering of Arab foreign ministers in Cairo three months later, Erdoğan hailed the Arab revolutions, called for "more freedom, democracy and human rights", and added:

We are elements of the same body and the same soul, for we constitute one great and noble family. Within a family, when joys are shared they increase, and when sorrows are shared they decrease. Now we are at a historical turning point where we share our joys and sorrows at the highest level...The time has come for us, who with all our different languages share the same conceptual geography and destiny, to take charge of our shared future...The people of this region, who for centuries have inaugurated new epochs in human history and authored new innovations from science to literature, from art to philosophy, are not-I am sorry to say-where they should be today. But we possess more than sufficient potential to turn this around, and we view the developments taking place today from this perspective. (Turkish Prime Ministry, 2011, 13 September)

Erdoğan's comments highlight not just the growing assertiveness of AK Party discourse in this latest phase, but also the accelerating convergence between the party's domestic and foreign agendas. Domestically, the elections were soon followed by the resignations of the chief of staff and three force commanders (unhappy about the ongoing coup plot investigations), and their replacement by a new military leadership that appeared intent on avoiding interference in political affairs. Erdoğan then initiated a new round of dialogue with the PKK that included a meeting between his intelligence chief Hakan Fidan and imprisoned PKK leader Abdullah Öcalan in December 2012. These talks seem to have yielded significant results, as the PKK implemented a ceasefire in March 2013, and began withdrawing its fighters from Turkey into northern Iraq. Erdoğan for his part convened a "Wise Men" commission in March to begin educating the public about the peace initiative, unveiled a new round of cultural reforms in September, and on 16 November 2013 met with the Iraqi KRG leader Mas'ud Barzani in Diyarbakir.

At each key juncture, the two sides cast their reconciliation efforts as part of a broader reassessment of the regional disposition drawn up by the colonial powers during World War I, and exemplified by the 1916 Sykes-Picot Agreement carving the Middle East into Western zones of influence. Speaking in Diyarbakır during his meeting with Barzani, for example, Erdoğan declared: "A century ago borders were drawn on this land with rulers, but they cannot draw borders on our affection. They cannot draw borders on our shared history, our shared civilization, our shared future" (CNN Türk, 2013, November 16). Öcalan-somewhat startlingly for 
a Kurdish nationalist-made the same point in his speech announcing the ceasefire, when he lambasted "Western imperialism" for dividing the "Arab, Turkish, Persian and Kurdish communities" into "nation-states and artificial borders", recalled their "common life under the banner of Islam for almost a 1000 years", and declared that "it is time to restore to the concept of 'us' its old spirit and practice" (CNN Türk, 2013, March 21).

The centerpiece of the AK Party's democratizing reforms from the very beginning-a Kurdish initiative that sought to replace monocultural secular nationalism with a more expansive communal identity based on Islam-thus inevitably had external ramifications as well. First, it provoked unease in neighboring states which viewed it as a threat to their own sovereignty. Tensions with Iraq, for example, came to the fore in 2011 as growing Turkish-KRG political and economic ties bypassed the Iraqi central government, with Turkish officials increasingly prone to visit Iraqi Kurdistan without stopping in Baghdad first, and with plans moving ahead for direct oil exports from the KRG region to Turkey. Prime Minister Nouri al-Maliki accused Turkey of meddling in Iraqi affairs in December 2011, and of acting like a "hostile" state the following April. KRG leaders, by contrast, now called Turkey a "strategic partner" (Bozkurt, 2012, May 7). By mid-2012, Turkey's traditional policy of propping up Baghdad against Iraq's Kurds had undergone a total reversal: "Privately, Turkish officials relate that if Baghdad strays far enough from Turkish interests, Ankara may decide to 'take Kurdistan under its wings'. The KRG agrees-[Mas 'ud] Barzani himself has reportedly suggested this sort of adoptive relationship...Both Kurdish and Turkish officials suggest that Ankara would be ready to defend the KRG if Baghdad moves with force to challenge Kurdish autonomy" (Çağaptay \& Evans, 2012, p. 9).

A second connection between the AK Party's domestic and foreign agendas emerged with the Arab upheavals of 2011. After a brief period of uncertainty, Erdoğan's government aligned decisively with the popular uprisings against authoritarian secular nationalist regimes: Tunisia's and Egypt's almost immediately, then Libya's, and finally-after a brief mediation attempt-Syria's as well. On 26 April 2012, Foreign Minister Davutoğlu made the connection explicit in a speech to the Turkish parliament in which he noted "fundamental changes" in "regional conceptions of statehood, governance, and human geography". Turkey's resources, including its government's credentials as architect of the "most important democratizing drive in the Turkish Republic's history", empowered it "to determine the future; to be the vanguard of a new idea, a new regional order". While acknowledging that Turkey's secular-nationalist opposition, preferring as it did a "Ba'thist political conception", could not be "expected to understand us", Davutoğlu declared that his government nevertheless intended "to direct the great transformation wave in the Middle East" (Turkish Ministry of Foreign Affairs, 2012, April 26). Speaking less than a year later, on the same day as Abdullah Öcalan's cease-fire speech, AK Party Deputy General-Secretary Süleyman Soylu made the link between his government's domestic and regional ambitions still more explicit when he said: "The third wave of democracy is very important for Turkey...We have been in a phase of retreat since 1699 [when the Treaty of Karlowitz marked the onset of Ottoman territorial decline]...[A]fter 300 years we are rising once again. There is now a Turkey that can lay claim to the lands which we dominated in the past" (Milliyet Newspaper, 2013, March 21).

The parallelism AK Party leaders drew between new conceptions of identity and representation at home on the one hand, and a new territorial order in the region on the other, drew precisely the responses Davutoğlu anticipated. At home, CHP leader Kemal Kılıçdaroğlu denounced the government's support for Syria's rebels as "a framework that approaches treason...We do not want our children's blood to be spilled in the Arab deserts" (CNN Türk, 2012, October 9). Abroad, President Assad of Syria opined that Erdoğan "thinks he is the new sultan of the Ottoman [sic] and he can control the region as it was during the Ottoman Empire under a new umbrella. In his heart he thinks he is a caliph" (RT Television, 2012, November 9). The Egyptian government installed by a military coup that ousted President Muhammad Morsi, and strongly backed by Saudi Arabia, for its part reacted to Turkish criticisms of its takeover and subsequent crackdown on the Muslim Brotherhood by expelling Turkey's ambassador in November 2013.

Davutoğlu's argument illuminates the fundamental dichotomy he-and his colleagues - see between their worldview and the one they ascribe to their primary opponents, foreign and domestic alike. Speaking in Diyarbakır on 15 March 2013, he elaborated on his side's alternative to the CHP's "Ba'thist conception", rejecting the "nationalist ideologies" with which the colonial powers had tried "to dismember us" and calling for a "new regional order" based on the restoration of an "older conception" of community (millet)-one that didn't differentiate between "Turk and Kurd, Albanian and Bosnian". Working together, "Turks, Kurds, Albanians, Bosnians, [and] Arabs" would erase "artificially drawn maps" and "break the mold that Sykes-Picot drew for us" (Turkish Ministry of Foreign Affairs, 2013, March 15). This is a vision that has been propounded consistently by Davutoğlu, Erdoğan and Gül since the early 1990s, as this article has sought to demonstrate, and as confirmed by recent content analyses of AK Party discourse revealing a quest for "great power identity" and a "politics of grandeur" (Demirtaş-Bagdonas, 2014) even in cases where public opinion was not supportive (Panayırcı \& İşeri, 2014, pp. 67-68; see also Gürcan, 2013, pp. 361-364, on the pro-AK Party me- 
dia). It is a vision that extends, as Davutoğlu's words indicate, well beyond the Middle East to Turkey's western and northern frontiers as well: Erdoğan's declaration in Prizren in October 2013 that "Turkey is Kosovo, Kosovo is Turkey", for example, provoked angry demonstrations in Serbia (Baydar, 2013, October 28). It is a vision, in short, that was always bound to generate serious problems with the adherents of secular nationalism in all the countries that fall within its purview, as well as with external forces - such as Russia, Israel and Iran-which have their own geopolitical reasons to oppose the consolidation of regional power it threatens to bring about.

\section{Conclusion}

The preceding analysis has sought to reveal the parallelism between the AK Party's drive against authoritarian secular nationalism at home, and its attempt to utilize both soft and hard power in pursuit of a new postnationalist regional order abroad, and thereby to indicate the inaptness of calls-primarily from Turkish and Western liberals - that it abandon "neo-Ottomanism" and concentrate on its domestic reform agenda instead. The same can be said of another line of criticism from an entirely different direction. In a series of columns published in January 2014, in a newspaper reflecting the views of Fethullah Gülen's Hizmet movement, Ali Bulaç argued that the AK Party leaders' "over-confident" and aggressive pursuit of their "neo-Ottoman delusions" is "un-Islamic" because it is predicated on Turkish leadership (Bulaç, 2014, January 2, 2014, January 4). In Islam, Bulaç asserted, leadership is assigned not to a particular nation but to the Islamic community (ümmet) as a whole, so considerations of power, history or geography are irrelevant: even the most humble Muslim may be appointed ruler (Bulaç, 2014, January 6).

This is one perspective in Islam, but it is not the only one. Ibn Khaldun (1332-1406), for example, a leading representative of the "Islamic realist" tradition Bulaç had denounced in his 2010 book, identified two criteria for effective leadership. The first is legitimacy, meaning adherence to the prevailing normative ethos (Islam, obviously, but increasingly in today's context democracy as well). The other is power-a point Ibn Khaldun illustrated by arguing, contrary to conventional opinion, that Quraysh, the Prophet's clan, forfeited their claim to rule when they "became too weak to fulfill the duties of the caliphate" (Muqaddima, 3.24). For Muslim realists, neither criterion can suffice without the other.

From this perspective, the AK Party leaders' appeal to Turkey's hard and soft power resources is not only legitimate, but mandatory. As for legitimacy, their adherence to Islam-and their consistent rejection of ethnic chauvinism-are evident. The question is, can they also maintain their democratic credentials? Erdoğan's responses to the two unexpected challenges that confronted him in 2013-the protests that broke out in May following the proposed closing of a park in Istanbul, and the crisis with Fethullah Gülen's movement that got underway in December-are noteworthy. In both cases, Erdoğan and his allies interpreted the crises as the work of their traditional adversaries: foreign actors fearful of Turkey's growing power and domestic secular-nationalist hardliners, now joined by Gülen's rival Islamist movement. Their heavy-handed responses have prompted questions about whether the AK Party can sustain its role as a democratic "dominant party" in the mode of Sweden's Social Democrats or Italy's and Japan's Liberal Democrats, or whether it may yet succumb to the authoritarian current in Turkish political culture (Keyman, 2014, pp. 24-25, 31; Çağla, 2012, p. 570).

While it is indeed the case, as the more fair-minded among those who raise such questions acknowledge, that much of the recent anti-government activism has constituted a "reactionary response" by the AK Party's traditional illiberal adversaries (Yel \& Nas, 2013, pp. $177,178)$, Erdoğan and his allies do appear to have missed an important dimension of the emerging opposition: the genuine Western-style liberals who have heretofore remained marginal, but who are destined eventually to eclipse the authoritarian secular-nationalists on both the political and normative levels. This point was vividly illustrated to me by a conversation with an oldschool Kemalist who drove many students to the Gezi Park protests in the summer of 2013. He said that when he encouraged the students to give no quarter as they battled the police, they looked at him as if he was crazy-they just wanted to defend the park, not kill policemen.

The immediate challenge posed by such crises to the AK Party leaders will be to test their ability to distinguish between their old opponents and these new liberals, and to recognize that each requires a different response. Counter-attacking by politicizing the judiciary and law-enforcement agencies, or censoring news outlets and social media sites, can only undermine the AK Party's democratic credentials, and hence its legitimacy, and hence its effectiveness at spearheading a new regional order. How artfully it deals with the looming flood tide of liberalism - philosophically and morally as well as politically-may well prove the ultimate challenge for the AK Party and for its attempt to formulate a credible Islamic-realist alternative.

\section{Conflict of Interests}

The author declares no conflict of interests.

\section{References}

Aras, B., \& Fidan, H. (2009). Turkey and Eurasia: Frontiers of a new geographic imagination. New Per- 
spectives on Turkey, 40, 195-217.

Balcı, A. (2010). 1990 sonrası Türk dış politikası üzerine bazı notlar: Avrupa Birliği ve Kıbrıs örneği. In C. Yenigün \& E. Efegil (Eds.), Türkiye'nin Değişen Dış Politikası (pp. 87-99). Ankara, Turkey: Nobel Yayın Dağıtım.

Baydar, Y. (2013, October 28). Erdogan: Kosovo is Turkey. Al-Monitor: Turkey Pulse News Service.

Bilgin, P., \& Bilgiç, A. (2011). Turkey's 'new' foreign policy toward Eurasia. Eurasian Geography and Economics, 52(2), 173-195.

Boland, V. (2007, April 2). Turkish growth boost for Erdogan. Financial Times Newspaper.

Bozdağlıoğlu, Y. (2008). Modernity, identity and Turkey's foreign policy. Insight Turkey, 10 (1), 55-76.

Bozkurt, T. (2012, May 7). Barzani: Türkiye'yi komşudan öte stratejik ortak olarak görüyoruz. Zaman Newspaper.

Bulaç, A. (1992). Medine vesikası hakkında genel bilgiler. Birikim Dergisi, 38-39,102-111.

Bulaç, A. (1993). Islam ve Demokrasi, Teokrasi, Totaliterizm. Istanbul, Turkey: Beyan Yayınları.

Bulaç, A. (2001). Din, Devlet ve Demokrasi. Istanbul, Turkey: Zaman Kitap.

Bulaç, A. (2010). Göçün ve Kentin iktidarı: Milli Görüş'ten Muhafazakar Demokrasi'ye AK Parti. Istanbul, Turkey: Çıra Yayınları.

Bulaç, A. (2014, January 2). Ne oldu da böyle oldu? Zaman Newspaper.

Bulaç, A. (2014, January 4). Doktrinin kritiği. Zaman Newspaper.

Bulaç, A. (2014, January 6). Kaçan fırsat. Zaman Newspaper.

Çağaptay, S., \& Evans, T. (2012). Turkey's Changing Relations with Iraq: Kurdistan Up, Baghdad Down (Policy Focus 122). Washington, DC, USA: Washington Institute for Near East Policy.

Çağla, C. (2012). Turkish politics: Raison d'État versus republic. International Review of Sociology, 22(3), 565-574.

Çakır, R. (1994). Ne Şeriat Ne Demokrasi: Refah Partisini Anlamak. Istanbul, Turkey: Metis Yayınları.

Çalışlar, O. (1995). Refah Partisi Nereden Nereye? Istanbul, Turkey: Pencere Yayınları.

Cemal, H. (2008, March 14). Kimse silahla biter demiyor. Milliyet Newspaper.

CNN Türk. (2012, October 9). Ihanete varan bir tezgah ile karşıkarşıyayız. CNN Türk News Service.

CNN Türk. (2013, March 21). Öcalan'ın Nevruz mesajı. CNN Türk News Service.

CNN Türk. (2013, November 16). Başbakan: Cezaevlerinin boşaldığını inşallah göreceğiz. CNN Türk News Service.

Davutoğlu, A. (1994a). Alternative Paradigms: The Impact of Islamic and Western Weltanschauungs on Political Theory. Lanham, USA: University Press of America.
Davutoğlu, A. (1994b). Civilizational Transformation and the Muslim World. Kuala Lumpur, Malaysia: Mahir Publications.

Davutoğlu, A. (2007). Stratejik Derinlik: Türkiye'nin Uluslararası Konumu. Istanbul, Turkey: Küre Yayınları.

Davutoğlu, A. (2013). Teoriden Pratiğe: Türk Dış Politikası Üzerine Konuşmalar. Istanbul, Turkey: Küre Yayınları.

Davutoğlu, A. (2013, March 21). Zero problems in a new era. Foreign Policy. Retrieved from http:// www.foreignpolicy.com/articles/2013/03/21/zero_ problems_in_a_new_era_turkey

De Bendern, P. (2009, March 25). Turkey breaks with past, seeks Iraqi Kurd ties. Reuters News Service.

Demirtaş-Bagdonas, Ö. (2014). Reading Turkey's foreign policy on Syria: the AKP's construction of a great power identity and the politics of grandeur. Turkish Studies, 15(1), 139-155.

Duran, B. (2013). Understanding the AK Party's identity politics: A civilizational discourse and its limitations. Insight Turkey, 15(1), 91-109.

Erbakan, N. (1975). Millî Görüş. Istanbul, Turkey: Dergâh Yayınları.

Erdoğan, R. T. (1993). Demokrasi amaç değil, araçtır. In M. Sever \& C. Dizdar (Eds.), 2. Cumhuriyet Tartışmaları: Yeni Arayışlar, Yeni Yönelimler (pp. 417-432). Ankara, Turkey: Başak Yayınları.

Erdoğan, R. T. (2002). Meeting with Mr. Recep Tayyip Erdogan. Center for Strategic and International Studies. Retrieved from http://csis.org/files/media/ csis/events/020128erdogan.pdf

Evin, A., Kirişci, K., Linden, R., Straubhaar, T., Tocci, N., Tolay, J., \& Walker, J. (2010). Getting to Zero: Turkey, Its Neighbors and the West. Washington, DC, USA: The Transatlantic Academy.

Gözen, R. (2010). Türk dış politikasında değişim var mı? In C. Yenigün \& E. Efegil (Eds.), Türkiye'nin Değişen Dış Politikası (pp. 19-35). Ankara, Turkey: Nobel Yayın Dağıtım.

Gül, A. (1993). Moral değerleri açısından Türkiye'nin millî bütünlüğü ve güvenliği. In İş Dünyası Vakfı, Türkiye’nin Milli Bütünlüğü ve Güvenliği: Türkiye Gönüllü Kültür Teşekkülleri III. Istişare Toplantısı 19 Aralık 1992, Ankara (pp. 116-125). Istanbul, Turkey: İş Dünyası Vakfı.

Gül, A. (2000). Interview with author. Ankara, 29 November 2000.

Gürcan, M. (2013). Theory or attitude? A comparative analysis of Turkish newspaper articles on Turkish foreign policy, June 2008-June 2011. Turkish Studies, 14(2), 346-371.

Hürriyet Newspaper. (2007, February 14). Büyükanıt: Türkiye'yi bölmeyi rüyada gören kabusla uyanır. Hürriyet Newspaper.

Hürriyet Newspaper. (2011, June 12). Başbakan'dan üçüncü balkon konuşması. Hürriyet Newspaper. 
International Crisis Group. (2010, April 7). Turkey and the Middle East: Ambitions and Constraints (Europe Report No. 203). Brussels, Belgium and Istanbul, Turkey: International Crisis Group.

İşeri, E., \& Dilek, O. (2011). The limitations of Turkey's new foreign policy activism in the Caucasian regional security complex. Turkish Studies, 12(1), 4154.

Kardaş, Ş. (2013). Turkey: A regional power facing a changing international system. Turkish Studies, 14(4), 637-660.

Keyman, E. F. (2009). Turkish Foreign Policy in the Era of Global Turmoil (SETA Policy Brief No. 39). Ankara, Turkey: Foundation for Political, Economic and Social Research.

Keyman, E. F. (2010). Globalization, modernity and democracy: Turkish foreign policy 2009 and beyond. Perceptions, 15(3-4), 1-20.

Keyman, E. F. (2014). The AK Party: Dominant party, new Turkey and polarization. Insight Turkey, 16(2), 19-31.

Kirişci, K. (2009). The transformation of Turkish foreign policy: The rise of the trading state. New Perspectives on Turkey, 40, 29-57.

Kirişci, K. (2011). Turkey's 'demonstrative effect' and the transformation of the Middle East. Insight Turkey, 13(2), 33-55.

Kirişci, K. (2012). Turkey's engagement with its neighborhood: A "synthetic" and multidimensional look at Turkey's foreign policy transformation. Turkish Studies, 13(3), 319-341.

Koç, Ş. A. (2010). Stratejik Dehlizlerde Derinlik Sarhoşluğu: Bir AKP Dış Politikası Eleştirisi (Special Report No. 10). Ankara, Turkey: 21. Yüzyıl Türkiye Enstitüsü.

Kutlay, M. (2011). Economy as the 'practical hand' of 'new Turkish foreign policy': A political economy explanation. Insight Turkey, 13(1), 67-88.

MacLeod, S. (2012). The Cairo Review interview: Strategic thinking. The Cairo Review of Global Affairs. Retrieved from http://www.aucegypt.edu/gapp/ cairoreview/pages/articleDetails. aspx aaid=143

Macovei, M. (2009). Growth and Economic Crises in Turkey: Leaving Behind a Turbulent Past? (European Commission Economic Papers 386). Brussels, Belgium: European Commission.

Milliyet Newspaper. (2013, March 21). AK Parti genel başkan yardımcısı Soylu: 300 yıl sonra yeniden yükseliyoruz. Milliyet Newspaper.

Mufti, M. (2009). Daring and Caution in Turkish Strategic Culture: Republic at Sea. Basingstoke, UK: Palgrave Macmillan.

Oğuzlu, T. (2010). The changing dynamics of TurkeyIsrael relations: A structural realist account. Mediterranean Politics, 15(2), 273-288.

Oppel, R. A., \& Al-Ansary, K. (2008, February 28). Gates urges limits on Turkish raids. New York Times
Newspaper

Özek, C. I. C., \& Oğuzlu, T. (2013). Beyond the institutional logics: International level systemic analysis of EU-Turkish relations. Turkish Studies, 14(4), 688708.

Panayırcı, U. C., \& İşeri, E. (2014). A content analysis of the AKP's 'honorable' foreign policy discourse: The nexus of domestic-international politics. Turkish Studies, 15(1), 62-80.

Radikal Newspaper. (2007, April 14). Sezer: Rejim tehdit altında. Radikal Newspaper.

Radikal Newspaper. (2007, June 13). Erdoğan bombaladı. Radikal Newspaper.

Reuters. (2008, March 10). US calls for dialogue with PKK. Reuters News Service.

RT Television. (2012, November 9). Bashar Assad interview. Retrieved from http://rt.com/news/assadinterview-exclusive-syria-265

Sarıbay, A. Y. (1985). Türkiye'de Modernleşme, Din, ve Parti Politikası: Millî Selâmet Partisi Örnek Olayı. Istanbul, Turkey: Alan Yayıncılık.

Tocci, N. (2012). Turkey as a Transatlantic Neighbor. In R. H. Linden, A. O. Evin, K. Kirişci, T. Straubhaar, N. Tocci, J. Tolay, \& J. W. Walker (Eds.), Turkey and Its Neighbors: Foreign Relations in Transition (pp. 195217). Boulder, USA: Lynne Rienner.

Tocci, N., \& Walker, J. (2012). From Confrontation to Engagement: Turkey and the Middle East. In R. H. Linden, A. O. Evin, K. Kirişci, T. Straubhaar, N. Tocci, J. Tolay, \& J. W. Walker (Eds.), Turkey and Its Neighbors: Foreign Relations in Transition (pp. 3560). Boulder, USA: Lynne Rienner.

Tolay, J., \& Linden, R. H. (2012). Introduction: Understanding Turkey's Relations with Its Neighbors. In R. H. Linden, A. O. Evin, K. Kirişci, T. Straubhaar, N. Tocci, J. Tolay, \& J. W. Walker (Eds.), Turkey and Its Neighbors: Foreign Relations in Transition (pp. 111). Boulder, USA: Lynne Rienner.

Tuğluk, A. (2008, March 17). Neo-ittihatçı projeler iflas etti. Yeni Şafak Newspaper.

Turkish Ministry of Economy. (n.d.). Retrieved from http://www.economy.gov.tr/index.cfm?sayfa=trad eagreements\&bolum $=\mathrm{fta} \&$ region $=0$

Turkish Ministry of Foreign Affairs. (2012, April 26). Ahmet Davutoğlu speech. Retrieved from http://www.mfa.gov.tr/disisleri-bakani-sayinahmet-davutoglu_nun-tbmm-genel-kurulu_ndasuriye_deki-olaylar-hakkinda-yaptigi-konusma_-26nisan-2012.tr.mfa

Turkish Ministry of Foreign Affairs. (2013, March 15). Ahmet Davutoğlu speech. Retrieved from http://www.mfa.gov.tr/disisleri-bakani-ahmetdavutoglu_nun-diyarbakir-dicle-universitesindeverdigi-_buyuk-restorasyon_-kadim_denkuresellesmeye-yeni.tr.mfa

Turkish Prime Ministry. (2011, September 13). Recep Tayyip Erdoğan speech. Gelecekleri ortak çizilmiş iki 
milletiz. Retrieved from http://www.basbakanlik. gov.tr/Forms/pActuelDetail.aspx

US Embassy in Ankara. (2008, March 5). Press statement. Retrieved from http://turkey.usembassy. gov/statement_030508.html

Uzgel, í. (2009). Dış politikada AKP: Stratejik konumdan stratejik modele. In i. Uzgel \& B. Duru (Eds.), AKP Kitabı: Bir Dönüşümün Bilançosu (pp. 357-380). Ankara, Turkey: Phoenix Yayınevi.

World Bank. (n.d.). Retrieved from http://data. worldbank.org/indicator/NE.TRD.GNFS.ZS?page=1
Yalvaç, F. (2012). Strategic depth or hegemonic depth? A critical realist analysis of Turkey's position in the world system. International Relations, 26(2), 165180.

Yanık, L. (2011). Constructing Turkish 'exceptionalism': Discourses of liminality and hybridity in post-Cold War Turkish foreign policy. Political Geography, 30(2), 80-89.

Yel, A. M., \& Nas, A. (2013). After Gezi: Moving towards post-hegemonic imagination in Turkey. Insight Turkey, 15(4), 177-190.

\section{About the Author}

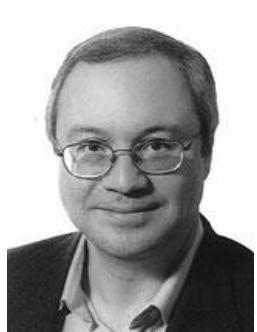

\section{Dr. Malik Mufti}

Malik Mufti is Professor of Political Science at Tufts University, where he teaches courses on international relations as well as the politics of the Middle East. He is the author of Sovereign Creations: PanArabism and Political Order in Syria and Iraq (1996), and Daring and Caution in Turkish Strategic Culture: Republic at Sea (2009). His most recent publications include studies of Ibn Khaldun on jihad and statecraft; evolving Islamic conceptions of democracy; and Francis Bacon's political and ethical thought from an Islamic perspective. He is currently working on a broader research project on realism in Islamic political thought. 